\title{
APLIKASI PUPUK KANDANG SAPI DAN AYAM TERHADAP PERTUMBUHAN DAN HASIL TANAMAN JAHE (Zingiber officinale Rosc.) DI MEDIA GAMBUT
}

The Application of Cattle Chicken Manures With Different Dosages on The Growth and Yield of Ginger (Zingiber officinale Rosc.) in Peat Media

\author{
YULIANA, ELFI RAHMADANI DAN INDAH PERMANASARI \\ Program Studi Agroteknologi, Fakultas Pertanian dan Peternakan, UIN Suska Riau \\ JI. H. R. Soebrantas Km. 15, Pekanbaru. \\ Email: Elfirahmadani@yahoo.co.id
}

\begin{abstract}
Research was conducted in march to june 2013 in the experimental farm of agriculture and animal Science faculty of the islamic university of sultan syarif Kasim Riau. The objektives of the research are 1.) to know the influence of chicken and cattle manures on plant grownt and yield of ginger 2.) and to find the best dosage of chicken and cattle manures for growth and yield of ginger. The experimental design was Randomized Complet Block Design Factorial RCBD with 2 factor 3 replications and analized by Duncan's Multiple Range Test DMRT. The first Factor was differents of manures (chicken and cattle) and the second factor is doses of manure $(0,5,10,15,20$, and 25 ton/ha). The data were collected for plant height, amount of plant, leaf width member of tillers/ plant and wet weight of rhizome. Results of the research showed that chicken manure increased plant height at 16 weeks and wet weight of rhizome. Wet weight of rhizome with chicken manure $28,18 \%$ was higher than cattle manure the best dosages of chicken and cattle manures was 5 ton/ha and in word plant height at 16 weeks, number of hears/ plant, number of tillers / plants and height of rhizomes. Aplication of 5 ton/ha of manures in wood number of tillers/ plant and wet weight of rhizome by $96,71 \%$ and $163,15 \%$ respectively.
\end{abstract}

Keyword: ginger (Zingiber officinale Rosc), chicken and cattle manures, growth, yield, peat media.

\section{PENDAHULUAN}

Jahe (Zingiber officinale Rosc) merupakan salah satu komoditas yang sudah sejak ribuan tahun yang lalu digunakan sebagai bagian dari ramuan rempah-rempah yang diperdagangkan secara luas di dunia. Masyarakat Indonesia umumnya telah mengenal dan memanfaatkan tanaman ini dalam kehidupan sehari-hari untuk berbagai kepentingan seperti: campuran bahan makanan, minuman, kosmetik, parfum dan lain-lain mulai dari tingkat tradisional di pedesaan sampai tingkat modern di perkotaan (Nitisapto dan Siradz, 2005). Tanaman jahe untuk dikonsumsi segar di panen pada umur 8 bulan, sedangkan untuk keperluan bibit dipanen umur 10 bulan atau lebih. Sementara untuk keperluan asinan jahe, jahe awet dipanen muda berumur 3-4 bulan( BBPPTP, 2008). Jahe juga mengandung gizi cukup tinggi antara lain $58 \%$ pati, 8\% protein, 3-5\% oleoresin dan 1-3\% minyak atsiri (Sari et al.,2006).

Sejak zaman dahulu jahe sudah sangat dikenal sebagai bumbu masak dan obat. Sampai sekarang masih dibutuhkan masyarakat luas untuk keperluan tersebut. Menurut badan kesehatan dunia (WHO), jahe masih menduduki urutan tertinggi sebagai obat tradisional yang paling banyak di dunia (Lukito, 2007 cit. Lesmana 2008). Pasokan jahe di pasaran dunia saat ini dikuasai oleh India ( $50 \%$ dari kebutuhan dunia), sedangkan Indonesia baru mampu mengekspor sebesar 34.564 ton dengan nilai US \$18.039.000 pada tahun 1997. Ekspor jahe tahun 2000 meningkat menjadi 43.192 ton, tetapi karena harganya menurun maka perolehan devisa hanya senilai US \$14.120.000 (BPS, 2003). Tahun 2002, mengalami penurunan drastis hanya 7.471 ton dengan nilai US $\$ 4.029 .000$ (Ditjenbun, 2004). Pada tahun 2004, produksi jahe nasional (104.789 ton) mengalami penurunan sebesar 20.597 ton jika dibandingkan tahun 2003 (12.5386 ton). Penurunan produksi tersebut disebabkan oleh turunnya produksi disentra pengembangan jahe utama yaitu di Jawa barat (BPS, 2004).

Santosa (1994) cit.Lesmana (2008) menyatakan jahe membutuhkan ruang terbuka dan membutuhkan cahaya matahari secara penuh. Selama fase pembentukan anakan, jahe membutuhkan banyak sinar matahari agar 
pertumbuhannya optimal. Jika ditanam di tempat yang agak terlindung misal di pekarangan, jahe berdaun lebar dan rimpangnya kecil. Salah satu sumber hara yang dapat digunakan dalam sistem pertanian organik adalah bahan organik yang berasal dari pupuk kandang, pupuk hijau, limbah pertanian, pupuk hayati, dan limbah rumah tangga atau perkotaan. Sumber hara yang juga diperkenankan dalam sistem pertanian organik adalah bahan galian tambang berupa kapur, batuan fosfat, biosuper atau campuran batuan dan mikroorganisme yang membantu proses pelapukan dan pelepasan hara (Melati dan Andriyani, 2005).

Pupuk kandang memiliki sifat yang alami dan tidak merusak tanah, menyediakan unsur makro (nitrogen, fosfor, kalium, kalsium, dan belerang) dan mikro (besi, seng, boron, kobalt, dan molibdenium). Selain itu, pupuk kandang berfungsi untuk meningkatkan daya tahanterhadap air, aktivitas mikrobiologi tanah, nilai kapasitas tukar kation dan memperbaiki struktur tanah. Pengaruh pemberian pupuk kandang secara tidak langsung memudahkan tanah untuk menyerap air. Pemakaian pupuk kandang sapi dapat meningkatkan permeabilitas dan kandungan bahan organik dalam tanah, dan dapat mengecilkan nilai erodobilitas tanah yang pada akhirnya meningkatkan ketahanan tanah terhadap erosi. Pupuk kandang ayam dapat memberikan kontribusi hara yang mampu mencukupi pertumbuhan bibit tanaman, karena pupuk kandang ayam mengandung hara yang lebih tinggi dari pupuk kandang lainnya (Santosoet al., 2004).

Pupuk kandang sapi dan ayam memiliki efek terhadap kesuburan tanah gambut yang cukup baik karena mengandung unsur hara yang lengkap (makro dan mikro) serta mikroorganisme yang ada di dalamnya mampu menguraikan gambut menjadi lebih matang sehingga beberapa unsur hara dalam gambut seperti $P$ mudah tersedia bagi tanaman. Dengan demikian, pupuk kandang akan memperbaiki kondisi fisik dan kesuburan gambut (Prastowo, 1993 cit. Najiyati et al.,2005).

Pupuk kandang dapat diperoleh dari kandang ternak sendiri seperti sapi, kerbau, kuda, kambing, babi dan ayam. Produksi pupuk masing-masing hewan tersebut tidak sama tergantung jenis dan ukuran/berat badan. Seekor sapi dewasa, rata-rata menghasilkan 5 ton pupuk matang/tahun, kerbau dewasa menghasilkan 10 ton/tahun, kuda mampu memproduksi pupuk 5 - 8 ton/tahun, kambing 0,6 - 0,9 ton/tahun, dan babi menghasilkan pupuk 1,4 - 1,7 ton/tahun (Soediyatno dan
Hadmadi, 1999 cit. Najiyati et al., 2005). Indonesia memiliki lahan gambut terluas diantara negara tropis, yaitu sekitar 21 juta ha dan tersebar terutama di Sumatera, Kalimantan dan Papua. Namun, variabilitas lahan ini sangat tinggi baik dari segi ketebalan gambut, kematangan maupun kesuburannya sehingga tidak semua lahan gambut layak untuk areal pertanian. Di Indonesia hanya sekitar 6 juta ha yang layak untuk pertanian(BBLitbang SDLP, 2008).

Perluasan pemanfaatan lahan gambut meningkat pesat di beberapaprovinsi yang memiliki areal gambut luas, seperti Riau, Kalimantan Barat danKalimantan Tengah. Pada tahun 1982 sampai 2007 telah dikonversi lahan seluas 1,83 juta ha atau $57 \%$ dari luas total hutan gambut seluas 3,2 juta ha di Provinsi Riau. Laju konversi lahan gambut cenderung meningkat dengan cepat, sedangkan untuk lahan non gambut peningkatannya relatif lebih lambat (Agus dan Subiksa,2008).

Berdasarkan hasil penelitian Elisman (2001) diketahui pupuk kandang ayam dapat memperbaiki sifat fisik dan kimia tanah sehingga tanah menjadi lebih gembur. Sementara Baherta (2009) menjelaskan kandungan kotoran ayam dalam setiap tonnya adalah $10 \mathrm{~kg} \mathrm{~N}, 8 \mathrm{~kg} \mathrm{P205,} \mathrm{dan} 4 \mathrm{~kg} \mathrm{K2O}$. Jumlah pemberian pupuk kandang ayam ratarata yang biasa diberikan di Indonesia berkisar 20-30 ton/ha. Apabila pemberian dosis pupuk kandang berkurang akan mengakibatkan pertumbuhan bibit kopi arabika semakin rendah. Menurut Widowati et al. (2004), pemberian pupuk kandang ayam menghasilkan produksi tertinggi pada tanaman sayuran selada pada tanah andosol Cisarua dengan takaran optimum \pm 25 ton/ha. Demikian pula hasil penelitian Suastika et al.,(2005) diperoleh hasil yang sama dimana pemberian pupuk kandang ayam takaran 1 ton/ha pada tanah Oxisol Pleihari menghasilkan 4,21 ton/ha jagung.Sedangkan menurut Susanti (2007), tanaman kolesum yang ditanam menggunakan benih yang diberi pupuk kandang ayam 15 ton/ha memiliki jumlah cabang tertinggi dan meningkatkan tajuk tanaman kolesum sebesar $34,15 \%$ dibandingkan tanpa pemupukan.Berdasarkan permasalahan diatas maka tujuan penelitian ini adalah: (1) Mengetahui pengaruh pemberian pupuk kandangayam dan sapi terhadap pertumbuhan dan hasil tanaman jahe; dan (2). Mendapatkan dosis pemberian pupuk kandang ayam dan sapi yang terbaik untuk meningkatkan pertumbuhan dan hasil tanaman jahe. 


\section{BAHAN DAN METODE}

Penelitian dilaksanakan pada bulan Maret sampai dengan bulan Juni 2013 di kebun percobaan Fakultas Pertanian dan Peternakan Universitas Islam Negeri Sultan Syarif Kasim Riau, terletak di Jalan H. R. Soebrantas No. 155 KM. 16 Pekanbaru. Penelitian menggunakan Rancangan Acak Kelompok (RAK) Faktorial dengan 2 faktor dan 3 ulangan. Faktor pertama adalah jenis pupuk kandang (ayam dan sapi) dan faktor kedua adalah dosis pupuk kandang $(0,5,10,15,20$ dan 25 ton/ha) sehingga dari kedua factor tersebut didapatkan 12 kombinasi perlakuan. Jika diperoleh nilai $\mathrm{F}$ hitung yang lebih besar dari $\mathrm{F}$ tabel $5 \%$ pada sidik ragam maka dilakukan uji lanjut dengan Duncan Multiple Range Test ( DMRT).

Bahan perbanyakan yang digunakan pada penelitian ini adalah rimpang yang berumur 9-12 bulan berasal dari petani jahe di Kec. Rumbai Pekanbaru.Pembibitan dilakukan dengan cara rimpang jahe dipotong-potong dengan ukuran antara $\pm 35-60 \mathrm{~g}$ danjahe mempunyai 2 mata tunas. Rimpang jahe disemaikan pada keranjang dengan ukuran $50 \times 50 \mathrm{~cm}$ dengan media tanah dan ditanam dengan kedalaman $3-7,5 \mathrm{~cm}$. Pemupukan tanaman jahe dilakukan 3 hari sebelum tanam dengan pemberian TSP $10 \mathrm{~g} /$ polybag dan $\mathrm{KCl}$ $5 \mathrm{~g} /$ polybag. Pengamatan penelitian dilakukan saat tanaman memasuki 4 bulan ( 120 hari setelah tanam) yaitu tinggi tanaman, jumlah daun, lebar daun terlebar/tanaman, jumlah anakan/tanaman, dan berat basah rimpang (gram).

\section{HASIL DAN PEMBAHASAN}

$\begin{array}{rlr}\text { Hasil } & \text { analisis } & \text { sidik ragam } \\ \text { menunjukkan } & \text { bahwa perbedaan pupuk }\end{array}$ kandang berbeda nyata terhadap tinggi tanaman minggu ke 16. Sedangkan perbedaan dosis juga berpengaruh nyata terhadap tinggi tanaman. Rerata tinggi tanaman terhadap perbedaan dosis pupuk kandangayam dan sapi dapat dilihat pada Tabel 1.

Tabel 1. Tinggi Tanaman, Jumlah Daun, Lebar Daun Terlebar, Jumlah Anakan dan Berat Basah pada tanaman Jahe pada Berbagai Dosis dan Perbedaan Pupuk Kandang Ayam dan Sapi.

\begin{tabular}{lccccc}
\hline \multicolumn{1}{c}{ Perlakuan } & $\begin{array}{c}\text { Tinggi } \\
\text { Tanaman }(\mathrm{cm})\end{array}$ & $\begin{array}{c}\text { Jumlah Daun } \\
\text { (helai) }\end{array}$ & $\begin{array}{c}\text { Lebar Daun } \\
\text { Terlebar }(\mathrm{cm})\end{array}$ & $\begin{array}{c}\text { Jumlah } \\
\text { Anakan }\end{array}$ & $\begin{array}{c}\text { Berat Basah } \\
(\mathrm{gram})\end{array}$ \\
\hline Pupuk kandang & & & & & \\
Ayam & $67,28^{\mathrm{a}}$ & $21,22^{\mathrm{a}}$ & 2,10 & $9,61^{\mathrm{a}}$ & $77,31^{\mathrm{a}}$ \\
Sapi & $63,22^{\mathrm{b}}$ & $21,11^{\mathrm{a}}$ & 2,00 & $9,22^{\mathrm{a}}$ & $60,31^{\mathrm{b}}$ \\
Dosis pupuk kandang & $\left(\begin{array}{l}\mathrm{b} / \mathrm{ha}) \\
0\end{array}\right.$ & & & & \\
5 & $56,00^{\mathrm{b}}$ & $15,17^{\mathrm{c}}$ & 1,88 & $5,17^{\mathrm{b}}$ & $35,72^{\mathrm{c}}$ \\
10 & $65,17^{\mathrm{a}}$ & $24,00^{\mathrm{ab}}$ & 2,12 & $10,17^{\mathrm{a}}$ & $94,00^{\mathrm{a}}$ \\
15 & $67,83^{\mathrm{a}}$ & $19,00^{\mathrm{bc}}$ & 2,02 & $10,17^{\mathrm{a}}$ & $75,69^{\mathrm{a}}$ \\
20 & $65,33^{\mathrm{a}}$ & $18,33^{\mathrm{bc}}$ & 1,98 & $9,50^{\mathrm{a}}$ & $71,30^{\mathrm{ab}}$ \\
25 & $68,67^{\mathrm{a}}$ & $23,33^{\mathrm{ab}}$ & 2,15 & $11,67^{\mathrm{a}}$ & $63,23^{\mathrm{b}}$ \\
\hline
\end{tabular}

Keterangan : angka-angka pada kolom yang sama yang diikuti oleh huruf yang sama tidak berbeda nyata pada taraf $5 \%$ menurut UJD.

\section{Tinggi Tanaman}

Tabel 1. memperlihatkan pemberian pupuk kandang ayam memiliki tinggi tanaman jahe tertinggi dari pada pemberian pupuk kandang sapi. Tinggi tanaman dengan pemberian dosis pupuk kandang ayam berkisar antara $67,28 \mathrm{~cm}$ dan pemberian dengan pupuk kandang sapi berkisar antara $63,22 \mathrm{~cm}$ pada umur 16 minggu setelah tanam. Hal ini dipertegas oleh hasil penelitian Adil et al. (2006) yang menjelaskan bahwa pupuk yang berasal dari kotoran ayam lebih baik dari kotoran sapi (mudah terurai didalam tanah sehingga dapat lebih mudah diserap oleh tanaman sayuran tomat,okra dan bayam).

Pemberian berbagai dosis pupuk kandang ayam dan sapi memperlihatkan rerata tinggi tanaman tertinggi pada dosis 20 ton/ha yaitu $68,67 \mathrm{~cm}$ yang tidak berbeda nyata dengan pemberian dosis $5,10,15,25$ ton/ha tetapi berbeda nyata dengan dosis 0 ton/ha yang memiliki tinggi tanaman terendah yaitu $56,00 \mathrm{~cm}$. Pertambahan dosis pupuk kandang menghasilkan pertumbuhan tinggi tanaman yang lebih baik bagi tanaman karena pupuk ini dapat meningkatkan bahan organik tanah dan ketersediaan unsur hara sehingga berpengaruh terhadap tinggi tanaman. Menurut Mangungsong (1991) cit. Baherta (2002), pupuk kandang berfungsi untuk meningkatkan tekstur tanah, agregat tanah, daya pegang air, kapasitas tukar kation, dan meningkatkan unsur hara bagi tanaman.

Pupuk kandang mengandung unsur hara nitrogen yang berfungsi untuk pembentukan asimilat, terutama karbohidrat dan protein serta sebagai bahan penyusun klorofil yang dibutuhkan dalam proses 
fotosintesis. Adanya nitrogen yang cukup pada tanaman akan memperlancar proses pembelahan sel dengan baik karena nitrogen mempunyai peranan utama untuk merangsang pertumbuhan secara keseluruhan khususnya pertumbuhan batang sehingga memicu pada pertumbuhan tinggi tanaman (Syarif, 1985 cit. Riyawati, 2012).

\section{Jumlah Daun}

Perbedaan pupuk kandang juga tidak berpengaruh nyata terhadap jumlah daun pada minggu ke 16. Sedangkan perbedaan dosis berpengaruh nyata terhadap jumlah daun tanaman pada 16 minggu, rerata jumlah daun tanaman dengan menggunakan pupuk kandang sapi dan ayam berkisar antara (21,11- 21,22). Pemberian pupuk kandang ayam memperlihatkan jumlah daun tanaman tidak berbeda nyata dengan pupuk kandang sapi. Hal ini menunjukkan bahwa kedua jenis pupuk kandang yang diberikan, memberikan pengaruh yang sama terhadap pertumbuhan daun tanaman meskipun sebenarnya pupuk kandang ayam lebih baik di banding pupuk kandang sapi. Menurut Baherta (2009), kandungan kotoran ayam dalam setiap tonnya adalah $10 \%$ N, $8 \%$ P205, dan $4 \%$ K2O. Sedangkan Kandungan kotoran sapi tediri dari: N 2,04 \%, P 0,76 \%, K 0,82\%, Ca 1,29 \%, dan Mg 0,48\%(Syukur dan Indah, 2006). Selain itu diduga karena daun kekurangan unsur hara nitrogen yang menyebabkan daun menjadi kuning, dan daun menjadi gugur.

Pemberian berbagai dosis pupuk kandang ayam dan sapi terhadap jumlah daun terbanyak pada pemberian pupuk kandang 25 ton/hayaitu 27,17 helai yang tidak berbeda nyata dengan pemberian pupuk kandang dengan dosis 5 dan 20 ton/ha, namun berbeda nyata dengan dosis 0,10 , dan 15 ton/ha dan jumlah daun terendah diperlihatkan oleh perlakuan pada dosis pupuk kandang 0 ton/ha yaitu 15,17 helai. Penambahan pupuk organik dapat meningkatkan kandungan unsur hara yang ada di dalam tanah, sehingga dapat digunakan untuk pertumbuhan tanaman. Seperti dikemukakan oleh Rosmarkam (2001) bahwa pupuk kandang sapi dan ayam yang dicampur dengan tanah semakin lama diinkubasikan akan mengalami dekomposisi dan mampu menyediakan unsur hara bagi tanaman. Selain itu, pupuk organik dapat juga memperbaiki sifat fisika tanah.

\section{Lebar Daun}

Perlakuan pupuk kandang ayam dan sapi tidak berpengaruh nyata terhadap lebar daun terlebar yaitu berkisar antara 2,00 - 2,10 $\mathrm{cm}$. Interaksi antara penggunaan dosis dengan jenis pupuk kandang pada tanaman jahe juga tidak berpengaruh nyata terhadap lebar daun terlebar. Hal ini menunjukkan bahwa respon dari pupuk kandang ayam tidak berbeda dengan pupuk kandang sapi. Aisyah (2011) menambahkan pertumbuhan dan perkembangan tanaman merupakan suatu proses penting dalam perkembangbiakan suatu tanaman. Proses pertumbuhan ditandai dengan terjadinya peningkatan beberapa bagian tanaman seperti peningkatan tinggi tanaman, panjang daun, lebar daun, dan berat seluruh begian tanaman. Salisbury dan Ross (1995) menyatakan bahwa luas daun tanaman merupakan suatu faktor yang menentukan jumlah energi matahari yang diserap oleh daun dan akan menentukan besarnya fotosintesis yang dihasilkan.

\section{Jumlah Anakan}

Tabel 1. memperlihatkan jumlah anakan pada perlakuan pupuk kandang ayam dan pupuk kandang sapi tidak berbeda nyata, berkisar antara 9,22 - 9,61. Pemberian pupuk kandang 5 ton/ha secara nyata meningkatkan jumlah anakan jahe dengan persentase kenaikan $96,71 \%$. Jumlah anakan naik sampai dosis 5 ton/ha akan tetapi tidak ada kenaikan jumlah anakan diatas dosis tersebut. Abdul (2006) menyatakan bahwa pupuk organik yang dicampurkan dengan tanah semakin lama akan mengalami dekomposisi dan mampu menyediakan unsur hara bagi tanaman. Pemberian unsur hara yang cukup akan meningkatkan jumlah anakan per-polybag sehingga diharapkan dapat meningkatkan jumlah anakan rimpang yang pada akhirnya dapat meningkatkan produksi rimpang segar.

\section{Berat Basah Rimpang}

Perlakuan jenis pupuk kandang berpengaruh nyata terhadap berat basah rimpang. Begitu juga dengan dosis yang digunakan. Rerata berat basah rimpang pada perlakuan pupuk kandang ayam secara nyata lebih tinggi dari pada pupuk kandang sapi, dengan perbedaan sebesar $28,18 \%$. Adapun rerata berat basah rimpang dengan pemberian pupuk kandang ayam adalah 77,31 gram, sedangkan pupuk kandang sapi yaitu 60,31 gram. Menurut Supriati dan Herlina (2010), kandungan unsur hara pupuk kandang ayam terdapat 1,5\% N, 1,5\% P205 dan 0,8\% K20. Sedangkan kandungan unsur hara pupuk kandang sapi terdapat 0,5\% N, 0,2\% P205, dan 0,5\% K20. Widowati et al. (2004) menambahkan pemberian pupuk kandang ayam akan menghasilkan produksi tertinggi pada tanaman sayuran selada pada tanah andosol Cisarua dengan takaran optimum \pm 25 
ton/ha dibandingkan dengan pemberian pupuk kandang lainnya. Demikian pula hasil penelitian Suastika et al.(2005) diperoleh hasil yang sama dimana pemberian pupuk kandang ayam takaran 1 ton/ha pada tanah Oxisol Pleihari menghasilkan 4,21 ton/ha jagung sedangkan yang menggunakan pupuk kandang sapi dengan takaran dan fosfat alam tunisia yang sama hanya diperoleh 2,96 ton/ha.Menurut Susantiet al. (2007), tanaman kolesum yang ditanam menggunakan benih yang diberi pupuk kandang ayam 15 ton/ha memiliki jumlah cabang tertinggi dan meningkatkan tajuk tanaman kolesum sebesar $34,15 \%$ dibandingkan tanpa pemupukan. Sedangkan menurut Djazuli et al. (2009), aplikasi pupuk kandang ayam menghasilkan bobot daun, akar, dan total tanaman purwoceng lebih baik dibandingkan dengan pupuk kandang kambing, pupuk kandang sapi, dan pupuk kompos.

Berdasarkan data Tabel 1 juga menunjukkan bahwa perlakuan dosis pupuk kandang berpengaruh nyata terhadap berat basah rimpang tanaman jahe. Penggunaan dosis pupuk 5 ton/ha menghasilkan berat basah rimpang sebesar 94,00 gram yang tidak berbeda nyata dengan dosis 10,15 dan 25 ton/ha, namun berbeda nyata dengan pemberian 0 dan 20 ton/ha. Pemberian pupuk kandang dosis 5 ton/ha meningkatkan berat basah rimpang sebesar 163,15\%. Menurut Sudiarto dan Gusmaini (2004), untuk menghasilkan produktivitas yang tinggi tanaman jahe banyak menguras unsur hara, terutama nitrogen dan kalium. Ketersediaan unsur hara nitrogen dan kalium yang cukup diharapkan dapat memacu pertambahan bobot rimpang basah jahe. Hardjowigeno (2003) menyatakan kalium berfungsi untuk pembentukan pati, meningkatkan enzim, pembukaan stomata (mengatur pernafasan dan penguapan), mempengaruhi penyerapan unsur hara lainnya, mempertinggi daya tahan terhadap kekeringan, penyakit, dan mempengaruhi perkembangan akar.

Tanaman jahe nilai ekonomisnya terletak pada rimpangnya dan pemberian pupuk bertujuan untuk menghasilkan produksi yang maksimal. Pemberian pupuk kandang selain memberikan ketersediaan unsur hara yang lebih baik juga dapat memperbaiki sifat kimia, fisik, dan biologis tanah, sehingga perakaran dapat berkembang dengan baik dan dapat menyerap unsur hara dan air dengan optimal untuk pertumbuhan dan produksi tanaman.

\section{KESIMPULAN DAN SARAN}

\section{Kesimpulan}

1. Pemberian pupuk kandang ayam meningkatkan tinggi tanaman minggu ke 16 dan berat basah rimpang. Berat basah rimpang dengan pupuk kandang ayam $28,18 \%$ lebih tinggi dari berat basah rimpang dengan pupuk kandang sapi.

2. Pemberian berbagai dosis pupuk kandang ayam dan sapi yang terbaik yaitu dengan pemberian dosis pupuk kandang 5 ton/ha yaitu pada tinggi tanaman minggu ke-16, jumlah daun, jumlah anakan dengan persentase kenaikan $96,71 \%$, dan berat basah rimpang sebesar 163,15\%. Penelitian ini menyarankan bahwa sebaiknya perlu dilakukan penambahan dosis pupuk kandang ayam dan sapi untuk mendapatkan hasil yang optimum pada tanaman jahe dan penelitian ini juga perlu dilanjutkan untuk jenis tanaman lainnya.

\section{DAFTAR PUSTAKA}

Abdul, S. 2006. Kajian Pengaruh Pemberian Macam Pupuk Organik Terhadap Pertumbuhan dan hasil tanaman jahe di Inceptisol Karangayar. 2006, Jurnal IImu Tanah dan Lingkungan, 6(2) : 124-131.

Adil, W. H., N. Sunarlim, dan I. Roostika. 2006. Pengaruh tiga jenis pupuk nitrogen terhadap tanaman sayuran. Biodiversitas, 7(1) : 77-80.

Agus, F. dan M. Subiksa. 2008. Lahan Gambut Potensi Untuk Pertanian dan Aspek Lingkungan. Balai Penelitian dan World Agroforestry Centre (ICRAF). Bogor. 36 hal.

Aisyah, S. 2011. Pengaruh Urin Sapi Terfermentasi Dengan Dosis dan Interval Pemberian yang berbeda Terhadap Pertumbuhan Tanaman Sawi (Brassica juncea L). Skripsi. Program Studi Agroteknologi, Fakultas Pertanian dan Peternakan, Universitas Islam Negeri Sultan Syarif Kasim Riau.

Baherta. 2009. Respon Bibit Kopi Arabika Pada Beberapa Takaran Pupuk Kandang Kotoran Ayam. Jurnal IImiah Tambua, 8 (1) :467-472.

BB Litbang SDLP (Balai Besar Penelitian dan Pengembangan Sumberdaya Lahan Pertanian). 2008. Laporan Tahunan 2008, Konsorsium Penelitian dan Pengembangan Perubahan Iklim pada Sektor Pertanian. Balai Besar Penelitian dan Pengembangan Sumberdaya Lahan Pertanian, Bogor. 31 hal. 
BPS. 2003. Statistik Perdagangan luar Negeri Indonesia. Badan Pusat Statistik. Jakarta. 36 hal.

BPS. 2004. Statistik Tanaman Obat-obatan dan Hias. Badan Pusat Statistik. Jakarta. 36 hal.

Djazuli, M. Dan J. Pitono. 2009. Pengaruh jenis dan tarap pupuk organik terhadap produksi dan mutu purwoceng. Jurnal littri. 15 (1) : 40-45

Elisman, R. 2001. Pengaruh pemberian beberapa jenis pupuk kandang terhadap pertumbuhan bibit kopi Arabika(Coffee Arabika Var. Kartika 1). Skripsi. Fakultas Pertanian Universitas Taman Siswa. Padang Sari et al.,2006).

Harjowigeno, S. 1996. Pengembangan Lahan Gambut untuk Pertanian suatu Peluang Tantangan. Orasi Ilmiah Guru Besar Tetap Ilmu Tanah Fakultas Pertanian IPB, 22 Juni1996.56-73 hal.

Lesmana, Y. 2008. Respon pertumbuhan dan produksi jahe (Zingiber officinale Rocs.) sitim keranjang terhadap pemberian pupuk organik padat dan komposisi media tanam. Skripsi. Universitas Sumatera Utara.

Melati, M. dan Andriyani. 2005. Pengaruh pupuk kandang ayam dan pupuk hijau terhadap pertumbuhan dan produksi kedelai panen muda yang dibudidayakan secara organik. Buletin Agronomi. 33 (2) 8-15

Najiyati, S., L. Muslihat dan I.N.S Putra. 2005. Panduan Pengolahan Lahan Gambut untuk Pertanian Berkelanjutan. Bogor. Wetlands Internasional. 231 hal.

Nitisapto, N dan S. A. Siradz. 2005. Evaluasi lahan untuk pengembangan jahe pada beberapa daerah di Jawa Timur. Jurnal Lahan, 5 (2):15-19
Riyawati. 2012. Pengaruh residu pupuk kandang ayam dan sapi pada pertumbuhan sawi (Brassica juncea L. ) di Media Gambut. Skripsi. Program Studi Agroteknologi, Fakultas Pertanian dan Peternakan, Universitas Islam Negeri Sultan Syarif Kasim Riau.

Rosmarkam, A. 2001. Ilmu Kesuburan Tanah. Jurusan Tanah. Fakultas Pertanian. Universitas Gadjah Mada. Yogyakarta. 210 hal.

Santoso, B., F. Haryanti dan S.A. Kadarsih. 2004. Pengaruh pemberian pupuk kandang ayam terhadap pertumbuhan dan produksi serat tiga klon rami di lahan aluvial Malang. Jurnal Pupuk. 5(2):14-18.

Salisbury, F.B dan Ross. 1995. Fisiologi Tumbuhan. ITB. Bandung.

Suastika, I.W., M.T. Sutriadi, dan A. Kasno. 2005. Pengaruh pupuk kandang dan fosfat alam terhadap produktivitas jagung di Typic Hapludox dan Plintic Kandiudults. Kalimantan Selatan. In Prosiding SeminarNasional Inovasi Teknologi Sumber Daya Tanah dan Iklim. Buku II. Bogor, 14-15 September 2004. Pusat Penelitian dan Pengembangan Tanah dan Agroklimat. Bogor.HIm 191-201.

Susanti, H., .S. A. Aziz dan M. Melati. 2008. Produksi biomassa dan bahan bioaktif kolesum (Talinum Triangular Jacq) Berbagai Asal Bibit dan Dosis Pupuk Kandang Ayam. Buletin Agronomi, 36 (1) $48-55$

Sudiarto dan Gusmaini. 2004. Pemanfaatan bahan organik in situ untuk efisiensi budidaya jahe yang berkelanjutan. Jurnal Litbang Pertanian, 23(2). 37-45.

Supriati, Y dan E. Herlina. 2010. Bertanam 15 Sayuran Organik Dalam Pot. Penebar Swadaya. Depok. 156 hal. 


\section{J U R N A L AGROTEKNOLOGI Journal of Agrotechnology}

PENGARUH PEMBERIAN PUPUK KALIUM DAN CAMPURAN KOMPOS TANDAN KOSONG KELAPA SAWIT DENGAN ABU BOILER TERHADAP PERTUMBUHAN DAN HASIL TANAMAN BAWANG MERAH (Allium asacalonicum L.)

The Effect of Potassium Fertilizer and Compost Mixture of Oil Palm Empty Bunches with Boiler Ash on Growth and Yield of Onion (Allium ascalonicum L.)

Dian Fikri Alfian, Nelvia, Husna Yetti

DAMPAK PERKEBUNAN KELAPA SAWIT TERHADAP PEREKONOMIAN WILAYAH DI KABUPATEN ROKAN HULU

The Impact of Palm Plantation Development in the Economic Region in Rokan Hulu district Irsyadi Siradjuddin

OPTIMASI METODE ISOLASI DNA PADA Jatropha spp.

Optimation of DNA Isolation Method on Jatropha spp.

Kristianto Nugroho, Rerenstradika T. Terryana, dan Puji Lestari

ANALISIS SIFAT FISIKA TANAH GAMBUT PADA HUTAN GAMBUT DI KECAMATAN TAMBANG KABUPATEN KAMPAR PROVINSI RIAU

Analysis of Soil Physical Peat Land in Peat Forests in Tambang Sub-District, Kampar District, Riau Province

Susandi, Oksana, dan Ahmad Taufiq Arminudin

OPTIMASI NAA DAN BAP TERHADAP PERTUMBUHAN DAN PERKEMBANGAN TUNAS MIKRO TANAMAN KANTONG SEMAR (Nepenthes mirabilis) SECARA IN VITRO

Optimize Of NAA And BAP On Growth And Development Of Micro Shoots Pitcher Plant (Nepenthes Mirabilis)Through In Vitro

Rosmaina dan Dinni Aryani

APLIKASI PUPUK KANDANG SAPI DAN AYAM TERHADAP PERTUMBUHAN DAN HASIL TANAMAN JAHE (Zingiber officinale Rosc.) DI MEDIA GAMBUT

The Application of Cattle Chicken Manures With Different Dosages on The Growth and Yield of Ginger (Zingiber officinale Rosc.) in Peat Media

Yuliana, Elfi Rahmadani, dan Indah Permanasari 